\title{
Working
}

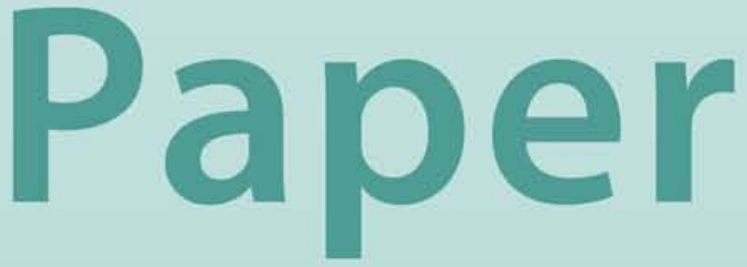




\section{Growth Slowdown in Bureaucratic Economic Systems: An Issue Revisited}

Zuzana Brixiová and Aleš Bulír 


\title{
IMF Working Paper
}

African Department and Policy Development and Review Department

\section{Growth Slowdown in Bureaucratic Economic Systems: An Issue Revisited}

Prepared by Zuzana Brixiová and Aleš Bulîŕ ${ }^{1}$

Authorized for distribution by Lelde Schmitz and Timothy D. Lane

January 2001

\begin{abstract}
The views expressed in this Working Paper are those of the author(s) and do not necessarily represent those of the IMF or IMF policy. Working Papers describe research in progress by the author(s) and are published to elicit comments and to further debate.
\end{abstract}

Bureaucratically organized systems tend to be less efficient than economies in which agents are free to choose their output targets, as well as the means to meet them. This paper presents a simple model of planner-manager interactions and shows how bureaucratic economies can end up in a low-effort, low-growth equilibrium even though they may have started in a high-effort, high-growth equilibrium. The empirical evidence from eight Central and Eastern European countries during 1948-89 is consistent with our model results, namely, that the growth decline was systemic in nature. The results are applicable to countries in other regions with heavy bureaucratic involvement in the economy.

JEL Classification Numbers:D73, O41, P21

Keywords: Bureaucracy, planning, growth.

Author's E-Mail Address: abulir@imf.org; zbrixiova@imf.org

${ }^{1}$ The authors thank Milf Bateman, Mark De Broeck, Joshua Charap, William Easterly, Rex Ghosh, Dan Ghura, Juha Kähkönen, Michael Keren, Tim Lane, Hongsung Moon, Alex Mourmouras, Lelde Schmitz, Tom Walter, and the participants of the 2000 meetings of the European Association for Comparative Economic Studies and IMF seminars for helpful comments. Fernanda Gusmao provided excellent secretarial support. 


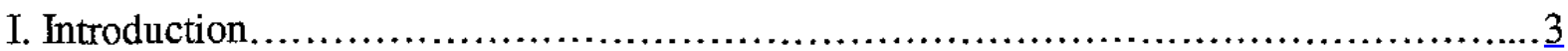

II. Bureaucratic Systems: Why Are They Inefficient? ................................

A. Central and Eastern European Economies: The Growth Record During 1949-89 ….......4

B. Some Competing Explanations of Growth Decline ........................................................

C. An Economy Where Everybody Wants to Meet the Targets........................................11

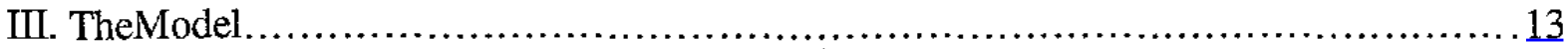

A. The Framework

B. Definition and Characterization of Equilibrium.......................................................16

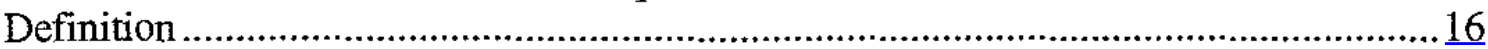

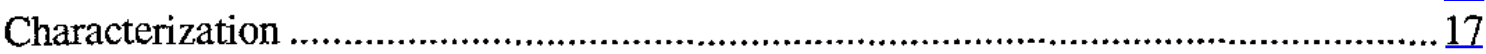

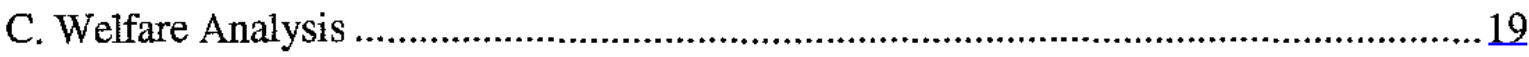

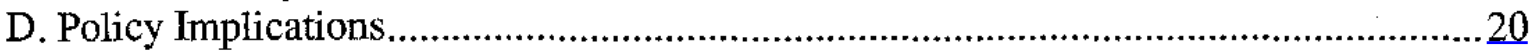

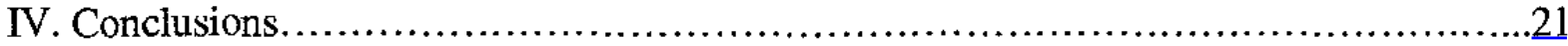

Appendixes

I. Econometric Tests of Growth Comovements Among the CEE Countries...............22

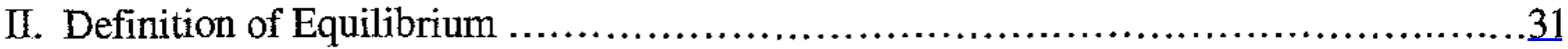

Text Tables

Table 1. Selected Countries: Estimates of Per Capita Income, 1970-90.................... I

Table 2. Selected Countries: Distribution of Net Material Product (NMP), 1970-89 .......... 1

Table 3. Did the U.S.S.R. Cause the Common Cycle?.................................. 8

Figures

Figure 1. Selected Countries: Trends in Net Material Product, $1949-89 \ldots \ldots \ldots \ldots \ldots \ldots \ldots \ldots 6$

Figure 2. Cost of Effort-Output Relationship ......................................... 19

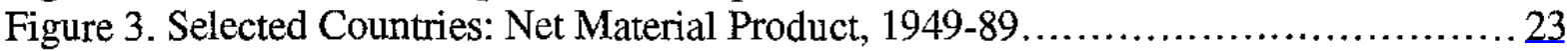

Appendix Tables

Table A1. The Rate of Growth in the CEE Countries Has a Negative Trend...............26

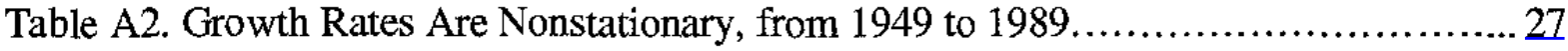

Table A3. Growth Rates Are Co-Integrated in a Panel Setting........................... 28

Table A4. Growth Rates Are Co-Integrated in Pairwise Tests of Co-Integration: Maximum

Eigenvalue and Trace Tests......................................................

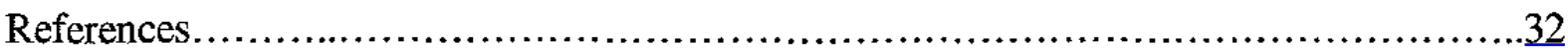




\section{INTRODUCTION}

Bureaucratically organized economic structures are usually less efficient than those structures in which agents are free to choose their output targets, as well as the means to meet them. Over time, market economies have outperformed command ones by a wide margin. However, disagreements remain regarding what is the main source of this difference. Is it the technical impossibility of designing an efficient plan or inability to implement such a plan? And why did most of these economies grow fast initially after planning was introduced, but slowed down later? We argue that the poor long-term growth performance of bureaucratic economic systems is related to the nature of the contract between the planner and the managers used in these economies. A hypothetical optimal contract could be neither constructed nor implemented, given the real-life constraints: penalties for underperformance could not be applied easily, and the planner could not design-for the complexity of the economy-individualized contracts with firms.

We model an economic system in which the planner may not offer sufficient incentives to firm managers to induce high-effort, high-output outcomes, and, as a result, the economy's rate of growth declines. The planner and firms are mutually dependent agents, that is, the planner loses if either plan targets are missed or these targets are set too low. Our motivation was to construct a simple model of planner-manager interactions and show how such an economy may end up in an inefficient, low-growth equilibrium. The model reflects the empirical evidence from eight Central and Eastern European (CEE) countries during 1948-89, namely, that the growth decline was systemic in nature.

The paper is organized as follows. First, we review the selecțed literature and stylized facts of bureaucratically organized systems, paying particular attention to CEE countries and their growth deceleration. Second, we formulate the objective functions of the planner and firm managers, discuss the contract between them, and assess the growth and welfare implications thereof. The final section concludes, and the Appendixes I and II contain some econometric results regarding the rates of growth of individual countries and the general solution to the consumer and planner problems, respectively.

\section{BUREAUCRATIC SYSTEMS: WHY ARE THEY INEFFICIENT?}

One of the main debates of the twentieth century was about the economic efficiency of nonmarket, bureaucratically organized economies. The comparative analysis was mostly seen as a competition between the capitalist West and communist East. This view is, however, too simplistic. On the one hand, other nonmarket or mixed systems than those of the Soviet bloc have been tried in practice, most of them with involvement of the state of one kind or another. Even the "Soviet bloc" generalization means little-the actual institutional structures differed markedly both among individual countries (say, the U.S.S.R. ${ }^{2}$ vs. Yugoslavia) and over time (say, Hungary in the 1950 s vs. Hungary in the 1980s). On the

\footnotetext{
${ }^{2}$ In this paper, the term "Union of Soviet Socialist Republics (U.S.S.R.)" will be used to
} refer to the Baltic countries, Russia, and the other countries of the former Soviet Union. 
other hand, these systems have had a lot in common: in general terms, this debate has been about the economics of bureaucracy, as discussed by Olson (2000). For example, the literature on information sharing between a regulator and a firm in a market economy (Baron and Besanko, 1984) is a mirror image of the "optimal tautness" literature on planning (Hunter, 1961; or Keren, 1991).

How do we define bureaucratic systems? Unlike in market systems, where the profit motive is the driving force, in bureaucratic systems the issue is how administrative pressure applied by the planner affects effort exerted by firms. We would argue that in these systems (i) the state either owns the means of production or has control over long-term investment decisions, and (ii) resources are allocated predominantly — but not necessarily exclusivelythrough planning. As a result, firms and consumers have a much narrower set of permissible activities than agents in free, market economies. In the remainder of this section we focus on a particular class of bureaucratically organized economies, namely, the CEE countries. After outlining the postwar growth record, we briefly discuss competing theories of the growth decline and describe the institutional setting of our model.

\section{A. Central and Eastern European Economies: The Growth Record During 1949-89}

Fast growth in the CEE economies (Bulgaria, Czechoslovakia, Hungary, Poland, the German Democratic Republic, Romania, the U.S.S.R., and Yugoslavia) following postwar recovery and nationalization lasted less than two decades, and by the 1970 s the growth average fell below that of the Organization for Economic Cooperation and Development (OECD) countries. ${ }^{3}$ Two basic observations warrant attention. ${ }^{4}$ First, the rate of growth rate of net material product (NMP) was high at the beginning of the period. Second, it began to decline some 10-15 years after the introduction of planning. We explore the stylized facts and use them as the empirical rationale for the model developed in the following section.

Dire initial projections notwithstanding, the CEE economies of the Soviet bloc did not collapse and, indeed, in 1950-65 grew faster than most market economies. ${ }^{5}$ Despite being denied access to their previously dominant foreign markets, missing out on transfers under

\footnotetext{
${ }^{3}$ A more technical discussion of the data and growth record is contained in the Appendix I.

${ }^{4}$ Although we used primarily examples from the former socialist countries, many of the observations can be generalized to encompass noncommunist, but statist, countries. For example, the growth deceleration in the Republic of Korea in the late 1970s was averted by curtailment and redirection of government interventions in the early 1980s (Crafts, 1999). In Ghana, the well-researched period of the 1960s and 1970s shows traits similar to those in the CEE countries (Frimpong-Ansah, 1991).
}

${ }^{5}$ This statement is true both for comparisons of actual growth rates and rates of growth based on a simple catch-up model, with the initial output per capita used as an explanatory variable (Murrell and Olson, 1991). 
the Marshall Plan, and having to reengineer their economies, the eight CEE countries started with NMP growth rates averaging in the double digits in the early 1950 s (Figure 1 ). The average rate slowed to about 5-8 percent in the 1960s and early 1970s and, thereafter, decelerated gradually to nil at $1988-89 .{ }^{6}$ As a result, personal consumption improved dramatically, the biggest increase being recorded in the 1950s and 1960s. At the same time, population grew modestly, and capital accumulation remained high-hence, the decline was attributable to a negative trend in total factor productivity (Pollard, 1991).

On average, the rate of growth deceleration was between -0.1 and -0.2 percentage point per annum during the 1949-89 period. The growth decay began long before the first oil shock, and the rate of growth declined in both oil-exporting countries (the U.S.S.R. and Romania) and oil-importing countries (the rest of the sample). Moreover, some of these countries were buying oil from the U.S.S.R. at highly distorted prices, while others were buying in the international market at the world prices (Yugoslavia).

A simple look at the trends in the rates of growth of these economies (Figure 1) shows that they grew at closely correlated rates. For most of the time, their trend growth rates stayed within a 1-2 percentage point band centered around the sample average. Although comovements of growth rates in neighboring countries are not a unique feature-it was documented for a large sample of African countries by Easterly and Levine (1998)-it is somewhat surprising in a sample that is heterogeneous both structurally and geographically. ${ }^{7}$ Moreover, the growth deceleration after 10-15 years was visible also in countries that started their planning systems at different times than the CEE countries and were not in geographical proximity to the CEE group - say, Cuba, Vietnam, or some developing countries in Africa. ${ }^{8}$

The growth decline in the CEE countries occurred notwithstanding the different levels of development and the different structures of their economies. Although the historic US\$ GDP per capita estimates are notoriously unreliable and difficult to compare, it is clear that in 1970 and 1980 per capita incomes in the German Democratic Republic or Czechoslovakia were still more than double those of Bulgaria, Romania, or

\footnotetext{
${ }^{6}$ Naturally, there were exceptions to the "rule" of a gradual decline: Hungary's output slumped in the mid 1950s as a result of the Soviet invasion, Czechoslovakia's output declined sharply in the early 1960 s owing to a particularly poorly designed five-year plan, Poland was hit by the debt crisis and Solidarity strikes in the early to mid-1980s, and so on.

${ }^{7}$ Easterly and Levine (1998), after controlling for geographical proximity, policies, investment, and so on, argue in favor of some underlying microeconomic conditions specific to the region.

${ }^{8}$ The only planned economy that escaped the growth trap was China in the 1980s by allowing bottom-up creation of new firms excluded from the state control and massive foreign direct investment.
} 
Figure 1. Selected Countries: Trends in Net Material Product, 1949-89

(Hodrick-Prescott filter, annual percentage change)

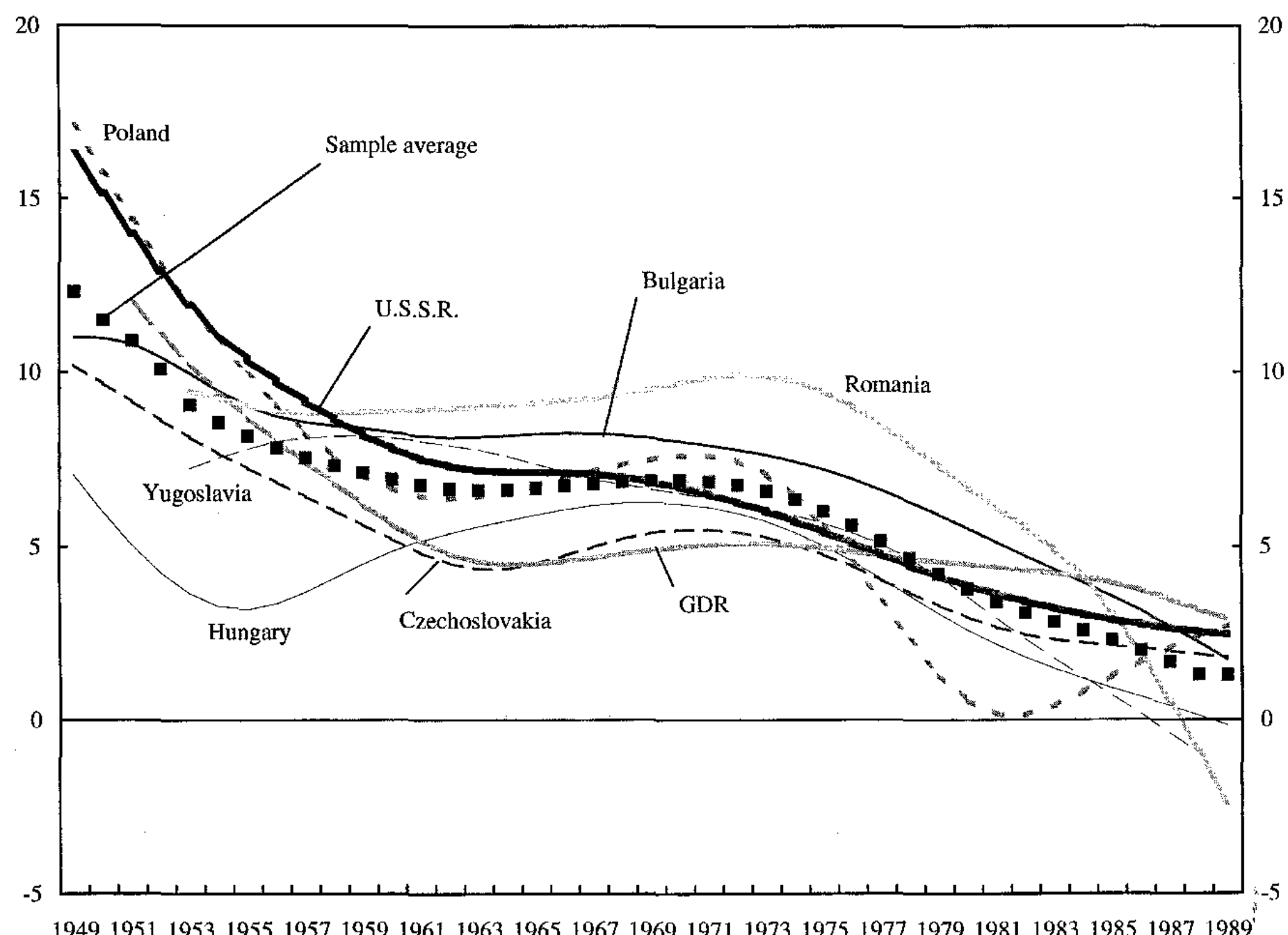


Yugoslavia (Table 1). While there was some convergence, major disparities in the level of development remained. A similar observation can be made with regard to the sectoral distribution of NMP in those countries. In 1970, three countries produced one-fourth or more of their NMP in agriculture, and only two countries seemed to have a significantly developed tertiary sector (Table 2). Although the differences narrowed substantially in the late 1980s, the group of the CEE countries was hardly homogeneous.

Table 1. Selected Countries: Estimates of Per Capita Income, 1970-90 (In U.S. dollars)

\begin{tabular}{|c|c|c|c|c|c|c|}
\hline & \multicolumn{2}{|c|}{1970} & \multicolumn{2}{|c|}{1980} & \multicolumn{2}{|c|}{1990} \\
\hline & $\begin{array}{l}\text { World } \\
\text { Bank }\end{array}$ & $\overline{\mathrm{CIA}}$ & $\begin{array}{l}\text { World } \\
\text { Bank }\end{array}$ & CIA & $\begin{array}{l}\text { World } \\
\text { Bank }\end{array}$ & CIA \\
\hline Bulgaria & & & 2,450 & & 2,320 & \\
\hline Czechoslovakia & & 2,008 & 2,980 & 5,041 & 3,140 & 8,265 \\
\hline Hungary $^{1}$ & 1,320 & 1,554 & 1,930 & 3,980 & 2,780 & 6,371 \\
\hline Poland & $\cdots$ & 1,245 & 1,520 & 3,542 & 1,690 & 4,531 \\
\hline German Dem. Rep. $^{2}$ & $\ldots$ & 2,016 & $\cdots$ & 5,574 & & 9,718 \\
\hline Romania & • & 1,155 & $\ldots$ & 3,406 & 1,620 & 4,151 \\
\hline Yugoslavia & 660 & 1,236 & 3,250 & 3,763 & 3,060 & 5,438 \\
\hline U.S.S.R. ${ }^{3}$ & & 2,461 & 2,776 & 5,985 & 3,783 & 9,521 \\
\hline
\end{tabular}

Source: World Bank, Historically Planned Economies: A Guide to the Data, 1993.

${ }^{1}$ The first World Bank estimate for Hungary is for 1977 .

${ }^{2}$ The last CIA estimate for the German Democratic Republic is for 1989.

${ }^{3}$ The last World Bank estimate for the U.S.S.R. is for 1988.

Table 2. Selected Countries: Distribution of Net Material Product (NMP), 1970-89 (In percent, calculated from NMP in constant prices)

\begin{tabular}{|c|c|c|c|c|c|c|c|c|c|}
\hline & \multicolumn{3}{|c|}{1970} & \multicolumn{3}{|c|}{1980} & \multicolumn{3}{|c|}{1989} \\
\hline & $\mathrm{A}$ & $\mathrm{I} \& \mathrm{C}$ & $\mathrm{S}$ & $\mathrm{A}$ & $\mathrm{I} \& \mathrm{C}$ & $\mathrm{s}$ & $\bar{A}$ & $\mathrm{I} \& \mathrm{C}$ & $S$ \\
\hline Bulgaria & 40 & 57 & 3 & 19 & 60 & 21 & 11 & 69 & 20 \\
\hline Czechoslovakia ${ }^{1}$ & 11 & 70 & 19 & 8 & 71 & 21 & 6 & 72 & 22 \\
\hline Hungary ${ }^{1}$ & 18 & 52 & 30 & 15 & 47 & 39 & 11 & 44 & 45 \\
\hline Poland & 24 & 61 & 15 & 13 & 63 & 24 & 14 & 60 & 26 \\
\hline German Dem. Rep. ${ }^{1}$ & 19 & 69 & 12 & 13 & 72 & 15 & 10 & 75 & 15 \\
\hline Romania & 28 & 58 & 13 & 16 & 66 & 18 & 15 & 66 & 19 \\
\hline Yugoslavia ${ }^{1}$ & 18 & 50 & 32 & 16 & 53 & 32 & 15 & 55 & 30 \\
\hline U.S.S.R. & 21 & 56 & 23 & 15 & 62 & 23 & 14 & 64 & 23 \\
\hline
\end{tabular}

Source: World Bank, Historically Planned Economies: A Guide to the Data, 1993. Notes: "A", "I\&C", and " $\mathrm{S}$ " indicate agriculture, industry and construction, and services, respectively.

${ }^{1} 1988$ data used for 1989 estimate. 
We are also skeptical about the hypothesis that the U.S.S.R. acted as the locomotive of growth for the rest of the CEE countries, an often proposed explanation of the growth comovement. ${ }^{9}$ First, cyclical fluctuations of the Soviet output are uncorrelated with all but a few countries (the German Democratic Republic, Czechoslovakia, and Poland), see Table 3 and Appendix I. Second, it is unclear through which channels the shocks would propagate. As shown by Ickes (1990a), intra-regional trade fluctuations were not causing growth fluctuations, owing, in part, to infrequently adjusted prices and exchange rates and negotiated volumes of trade. ${ }^{10}$ Third, reforms in the U.S.S.R. were not synchronized with those in the other Council of Mutual Economic Assistance (CMEA) countries (Adam, 1989). For example, countries used different firm-level planning targets: gross and net output, profit (both in levels and first differences), gross income, and so on (Majcher and Valach, 1988).

Table 3. Did the U.S.S.R. Cause the Common Cycle?

(Correlation coefficients of growth rates)

\begin{tabular}{lcrrrrrr}
\hline & Czechoslovakia & $\begin{array}{c}\text { German } \\
\text { Dem. Rep. }\end{array}$ & Hungary & Poland & Romania & Yugoslavia & U.S.S.R. \\
\hline Bulgaria & 0.036 & 0.140 & 0.482 & -0.054 & 0.169 & 0.310 & -0.240 \\
Czechoslovakia & & 0.383 & 0.344 & 0.128 & 0.327 & -0.288 & 0.240 \\
German Dem. & & & -0.107 & 0.111 & -0.060 & -0.006 & 0.426 \\
Rep. & & & 0.027 & 0.309 & -0.080 & -0.147 \\
Hungary & & & & 0.049 & 0.309 & 0.219 \\
Poland & & & & & -0.388 & -0.037 \\
Romania & & & & & & -0.005 \\
Yugoslavia & & & & & & &
\end{tabular}

Source: Authors' calculations.

Note: The individual country growth rates are defined as deviations from the series' HodrickPrescott filter.

\footnotetext{
${ }^{9}$ The Council of Mutual Economic Assistance did create initial conditions for fast industrialization and early growth in some of the less developed CEE economies, say, Bulgaria or Romania, by guaranteeing access to a large market for mostly low-quality, unsophisticated goods in exchange for cheap energy. See, for example, Marrese and Vañous (1983). By the same token, however, the more developed countries (Czechoslovakia or EastGermany) lost much of their competitive advantage by participating in this type of trade.

${ }^{10}$ The CMEA countries preferred self-sufficiency (or intra-regional trade) to international trade for various reasons, including those of ideology. A lack of comparative advantage resulting from the autarkic tendencies has contributed to a growth slowdown in the long run.
} 


\section{B. Some Competing Explanations of the Growth Decline}

What are the mainstream explanations and how do they fit the stylized facts about growth? Potential oversimplification notwithstanding, we argue that most of these explanations can be categorized into two main groups, with both of them starting from the hierarchical view of the planned economy (Ellman, 1990). The first explanation views the developments as the results of institutional changes, poorly chosen technology, and macroeconomic shocks. The second explanation assumes that planning simply cannot work owing to the coordination problem. Each of these theories has its strong points and fits some of the stylized facts quite well. However, neither of them seems to encompass all the facts.

The first explanation, a sort of "folk theorem" of planned economies, attributes the 1950 s growth spur to massive factor mobilization and the so-called extensive growth policies. "The communist regimes nationalized most or all of industrial production and subjected all firms to output targets. Open unemployment disappeared, women were drawn into the labor force in unprecedented numbers, and capital accumulation was greatly accelerated. In addition, most of these economies benefited initially from positive terms of trade shocks. The eventual deceleration in the $1970 \mathrm{~s}$ and $1980 \mathrm{~s}$ is-in this explanationattributed to the exhaustion of the initial factor stimulus, poor macroeconomic policies (Brada, 1989), the oil and debt-crisis shocks, credit shocks (Bulír, 1998), excessive defense spending (Landau, 1994), a loosely defined decline in working ethic, and so on.

The literature, however, hints at some problems with these motivations of the growth decline. The relatively high rates of growth were sustained into the early 1970s, some two decades past the initial factor mobilization. Bad policies were present throughout the sample period and not only in the 1970 s and 1980s. Moreover, the same extensive growth strategy was sustained for much longer in Japan and Korea.

Some economists went further and modeled the growth decay as a pure investment problem. The main line of argument was that the planned economies overinvested in fixed capital and that low substitution between capital and labor caused "acute diminishing returns to capital." ${ }^{12}$ In a way, this explanation is a version of the government-failure explanation: the blame for the poor technology choice is put on the planning authority. However, most of these theories did not examine optimizing behavior of agents in these economies and, as such, these theories explained neither why the particular type of technology was chosen, nor

${ }^{11}$ Unsustainability of the "extensive growth" policies without technological progress was recognized as early as in the late 1950 s by policymakers in the CMEA countries (Adam, 1989). Weitzman (1970) and Ofer (1987) define the extensive growth model.

${ }^{12}$ Sapir (1980) and Rusek (1989) estimated the elasticity of substitution of production factors for Yugoslavia and Czechoslovakia at about 0.1 . These estimates contrast with the almost unitary elasticity found in other extensively growing, but nonsocialist countries (see Easterly and Fischer (1995) for a review). 
who chose it. ${ }^{13}$ Although the overinvestment explanation of the eventual growth decline fits time series of the former U.S.S.R. or Czechoslovakia reasonably well, as was shown by Easterly and Fischer (1995) and Klacek and Nešporová (1984), respectively, there is no evidence that would validate this explanation in a panel setting. Still, the growth performance in the 1950s and 1960s was exceptional even after controlling for high investment, according to Easterly and Fischer (1995). Clearly, investment alone cannot explain the originially high growth and the eventual slowdown. ${ }^{14}$

The second group of authors focused on the well-known coordination problem of central planning (Hayek, 1940). Their argument was that once central planners moved beyond the relatively simple tasks of industrialization, war management, or postwar recovery, they simply could not handle the problem of coordinating the national economy. ${ }^{15}$ In particular, this critique stressed the problems entailed in introducing and evaluating innovations. The planning center could not reward firms with higher prices and abnormal profits: first, it lacked a market that would evaluate the usefulness of these innovations, and, second, price adjustments were infrequent. ${ }^{16}$ This explanation fits several features of the planned economies, most notably the obsolete character of goods produced therein. However, it fails to explain why it took 20 years for the rate of growth to slow down, or why the rate of growth declined in all countries, irrespective of their innovation cycle. One could argue that even the outdated goods could have been produced in the 1980s at the rates of growth of, say, the early 1970 s.

${ }^{13}$ In several CEE countries, especially during the 1980 s, the firms themselves made some of the technology decisions, and small-scale investment was completely decentralized. Parsons (1986) discussed this feature for the German Democratic Republic, but identical policies were implemented in Czechoslovakia (Buliri, 1995), as well as in the other CEE countries.

${ }^{14}$ Hernández-Catá (2000) demonstrated the ambiguous impact of investment in the case of Cuba-the total factor productivity component can dominate the medium-term rate of growth.

${ }^{15}$ Of course, substantial effort was devoted to formal proofs that a planning system can work as efficiently as the capitalist one. See, for example, Lange and Taylor (1938), Arrow and Hurwicz (1960), Hurwicz (1973), or Malinvaud (1967).

${ }^{16}$ That is not to say that the planners did not try. While the five-year, economy-wide price exercises were too infrequent, retail market pricing was gradually relaxed and "technological innovations" were often exempted from the markup calculations applied to "established" products. Of course, the resulting surge in firm-driven pseudoinnovations led eventually to price inflation as the established, low-priced goods were replaced by new, high-priced, but largely identical goods. Another suggestion was to impute price information from established Western markets. This approach had the same flaws as the previous one: exchange rates were unrealistic, and the planning center could not control for quality differences between the domestically produced products and the foreign-produced ones. 
A version of this explanation is the concept of shortage developed by Kornai (1980), who argued that growth rates under central planning had come down because producers could not find inputs in the quality or variety they needed. The bottlenecks would eventually choke the rate of growth or lower the quality of output. ${ }^{17}$ In this approach, the system would disintegrate into shortages and queuing because the plan in reality cannot be detailed enough. This approach, however, does not explain the dynamics of the process: why shoutd shortages become important only in the latter stages of the existence of planned economies? Moreover, the concept of shortage says nothing about shortages converging in all countries, forcing some sort of growth convergence. Indeed, the existing literature suggests that the problem of shortage varied across countries and over time (Dlouhý, 1990).

Having found the explanations in the planned-economy literature incomplete, we wondered whether other branches of economics provide better explanations. Promising inroads had been made by several principal agent studies, such as those by Freixas, Guesnerie, and Tirole (1985) or Keren (1991). ${ }^{18}$ While these papers outlined conditions under which the contracts between the planner and managers operate, they left unanswered some key questions. First, these papers modeled interactions of the planner with a single firm, usually in a static context. Hence, they yielded negligible results that would be applicable/testable in dynamic macroeconomic analyses. Second, the objective function of the planning authority unrealistically assumed a benevolent planning center, skillfully selecting production targets in order to maximize output and, therefore, total welfare. Still, by furnishing microeconomic foundations for the debate, their explanations provided technical apparatus that we use in the subsequent sections.

\section{An Economy Where Everybody Wants to Meet the Targets}

We disagree with the notion that planning failures are mostly due to a planner's mistakes. The reality has been usually more complex-for example, the planner may not have sufficient leeway to design and/or implement the optimal plan. In this section, we summarize some stylized facts about the planner-manager relationship that we explore formally in Section III.

First, the planning authority knows neither the true production functions of individual firms nor their capacity utilization. On the one hand, firms have a vested interest to hide this information to ensure both contemporaneous and future plan compliance. On the other hand, the planner possesses only a rudimentary monitoring technology. The available evidence suggests that most firms were reasonably good at the hide-and-seek game. Although this is a well-known feature of planned economies, many models assume some Bayesian learning processes through which the planner can eventually learn the true production functions of

\footnotetext{
${ }^{17}$ See Banerjee and Spagat (1992) for a simple model.

${ }^{18}$ See Keren (1993) for a review of these types of models.
} 
individual firms. In contrast with this literature, we assume that the planner knows only the distribution of production functions in the economy as a whole.

Second, the planner is concerned about compliance as much as the individual firms because he is penalized for economy-wide underperformance vis-à-vis the plan targets and, hence, is motivated to set the plan such as to minimize the risk of missing the plant targets. ${ }^{19}$ We see the planner as a selfish agent maximizing his own utility by keeping a portion of output for himself as opposed to maximizing "welfare of the people." At the same time, plan targets must be above some threshold, such as last year's output. Poorly designed plans, or plans that have been unsuccessful owing to some exogenous shocks, have had ruinous effects for their authors: from executions in the 1920s U.S.S.R. to more gentle career consequences later on. It is interesting to note that practically no annual or five-year plans were officially declared off track-there is ample evidence that either the plan targets were "adjusted," that is, lowered halfway through the planning period, ${ }^{20}$ or the actual, firm-level outturn was falsified, with the tacit approval of the planner. ${ }^{21}$ Of course, this was partly because both planners and firm managers belonged to the same elite.

Third, who would punish firms for underperformance and the planner for poor plans, and can an "optimal punishment" be devised? In most of these countries, either a dictator or a collective body oversaw the economy and set penalties. The penalties were initially quite harsh, including capital punishment. However, the ruler(s) soon recognized the declining efficiency of terror, as potential managers were not willing to accept responsibility for risky projects. 22 The empirical literature unambiguously suggests that the penalty for nonperformance declined in relative, as well as in absolute, terms as exhibited, for example, by bureaucrats' tenure. ${ }^{23}$ Moreover, the evidence suggests that the planner had only limited control over the consumption of managers - in most countries, wages in percent of NMP were gradually increasing.

${ }^{19}$ This line of argument has somehow never become a part of the mainstream thinking about planned economies. See, for example, Brada (1978), Hlaváček (1990), or Ickes (1990b) for evidence about risk minimizing behavior of firms under planning.

${ }^{20}$ See Keren (1982) for evidence on ex post adjustments, both down and up, of macroeconomic planning targets in the German Democratic Republic.

${ }^{21}$ Lubomír Mlčoch (1990a and 1990b) described the so-called planning games used in the former Czechoslovakia to fulfill formally the plan at the margin (price changes, changes in structure of output, overinvoicing, end-period repurchase agreements, etc). The planning games are an analogue to the "storming" pattern of enterprise behavior (Alexeev, 1991).

${ }^{22}$ The only country where the punishment seemed to have increased over time was Cambodia under the Pol Pot rule in the 1980s. The constant threat of capital punishment stimulated high effort at the cost of a devolution into one giant agricultural commune.

${ }^{23}$ This point was documented empirically using Czechoslovak and Hungarian data on bureaucrats' tenure by Faith and Short (1995). 
Fourth, the bureaucratically organized system limited the set of permissible activities and-following the rapid increase in personal consumption in the 1950s and 1960s-offered comparatively low return to effort. A manager himself could decide neither on the production of a new, profitable product, nor would he receive a portion of the profit. After achieving the average, "guaranteed" standard of living, managers and workers had little chance of wealth accumulation as "law abiding citizens." In the end, all CEE economies had compressed distributions of personal incomes-the 1988 Gini coefficient was 0.19 and 0.23 in Czechoslovakia and Hungary, respectively, some one-half of its value in countries with comparable GDP per capita (see Milanovic, 1994). ${ }^{24}$

\section{THE MODEL}

\section{A. The Framework}

The economy in our model is inhabited by two types of agents; a large number of managers, $M$, with population normalized to 1 , and one planner $(P)$. All agents live for two periods $(t=1,2)$ and have the same preferences in consumption described by $U\left(c_{t}^{M}(j)\right)$ in the case of managers and $U\left(c_{t}^{p}\right)$ in the case of the planner, where $c_{t}^{M}(j)$ is the consumption of a single good in period $t$ by a manager $j \in(0,1)$ and $c_{t}^{P}$ is consumption by the planner. Both agents are endowed with amount $w^{i}$ of the same good and $w^{M}$ and $w^{P}$ denote the endowments-identical in both periods-of managers and the planner, respectively.

At the beginning of each period, managers choose effort that they will put into production, $x_{t}, t=1,2$, to maximize their utility. This effort costs them $d\left(x_{t}\right)=x_{t}$ units of consumption good, where $\gamma>0$ is a cost parameter. ${ }^{25}$ The effort affects the probability distribution of the publicly observable output, is private information, and can take on two values, $x_{t} \in\{0,1\}$, where 1 is the high effort, and 0 is the low effort. A high (low) level of effort does not, however, guarantee that output will be high (low). We denote $\phi_{H}$ the

\footnotetext{
${ }^{24}$ Once a worker received his (state-owned) accommodation, bought (the only available) car, and perhaps also built his weekend cottage, he knew that he reached his bliss point. On the one hand, additional effort would yield some extra income for which the worker would have little or no use. On the other hand, once he reached his bliss point, the value of leisure increased dramatically. Anecdotal evidence regarding working habits in the CEE economies suggest that shirking was widespread—workers rarely stayed until the end of the work day, factories and offices were empty by midday on Fridays, and so on.
}

${ }^{25}$ An alternative way of thinking about the cost of effort is in terms of leisure foregone. Intuitively, managers need time to consume and additional effort shortens that time. 
probability of output being "high", given effort 1 , and $\phi_{L}$ the probability of output being "high", given effort 0 , where $\phi_{H}>\phi_{L}{ }^{26}$

With respect to output, we assume that the economy experiences some exogenous technological progress, $\varepsilon$, between periods 1 and 2 . More specifically, in period 1 managers produce output $z_{H}$ in "high output state", and output $z_{L}$ in "low output state", where $z_{H}-z_{L}=\sigma>0$. In period 2 managers produce $z_{H}+\varepsilon$ in "high output state" and $z_{L}+\varepsilon$ in "low output state", that is, output increases between period 1 and 2 by $\varepsilon$ in both high- and low-effort states. ${ }^{27}$ The potential aggregate output in period $t$, that is, the aggregate output under high effort, is then defined as

$$
\bar{Y}=Y_{H(t)}=\phi_{H} z_{H(t)}+\left(1-\phi_{H}\right) z_{L(t)}
$$

Moreover, we assume that potential output is public information, with both managers and planners knowing the aggregate production function, $\left(z_{H}, z_{L}\right)$, and the distribution, $\phi_{H}$.

Prior to the beginning of each period, the planner chooses a contract to maximize his utility. ${ }^{28}$ The contract is a set of explicit payoffs to the manager (conditional on the publicly observable output), and set of residual payoffs to the planner. Specifically, the contract is a couple $s_{t}=\left(s_{H(t)}, s_{L(t)}\right)$ that specifies the payoffs to managers at time $t$, and in states $H$ and $L$, respectively. We concentrate on the so-called linear contract, since this type of contract has been most frequently used. The linear contract determines payoffs to a manager as

$$
s_{t}^{M}=\left(\lambda_{t} z_{H(b)}, \lambda_{t} z_{L(t)}\right),
$$

${ }^{26}$ Throughout our model, $H$ takes on the interpretation of the "high-output state" and $L$ takes on the interpretation of the "low-output state."

${ }^{27}$ For convenience, we assume that $\sigma=\varepsilon$, however, relaxation of this assumption has no impact on generality of our results.

${ }^{28}$ In the rest of the paper we assume that all agents have preferences linear in consumption (risk neutral): $U\left(c_{t}^{i}\right)=c_{t}^{i}$, where $t=1,2 ; i \in\{M, P\}$. To focus our model on non-trivial solutions, we impose the following restrictions on parameters: $c_{\min }>w^{M}>\gamma$. This condition guarantees that the endowment of a manager is high enough to cover cost of high effort, but not high enough to cover minimum consumption, that is, managers always have an incentive to produce. Also, the minimum consumption reflects the high emphasis put on income equality in bureaucratic economies, as opposed to emphasis on efficiency placed in market economies. 
where $\lambda_{t}, 0 \leq \lambda_{t} \leq 1(t=1,2)$ is the share of output that the manager can keep in period $t$, and $z_{i(t)}=z_{i}$ in period 1 and $z_{i}+\varepsilon$ in period $2, i \in\{H, L\}$. Under this arrangement, payoffs to the planner are determined residually as $s_{t}^{P}=\left[\left(1-\lambda_{t}\right) z_{H(t)},\left(1-\lambda_{t}\right) z_{L(t)}\right] .{ }^{29}$ Moreover, the planner has an obligation to announce publicly a planned aggregate output, $\hat{Y}$. Since the planner designs contracts that are incentive compatible and since the aggregate production technology is public information, the planner knows whether managers put in high effort into production and to what aggregate output such effort would lead; consequently, the actual output equals the plan. ${ }^{30}$

In deciding the payoffs, the planner is constrained by several requirements. First, managers' individual consumption must stay above some minimum (subsistence) level, $c_{\min }$, in both periods. Second, if the plan/output is below its potential $(\hat{Y}<\bar{Y})$, the planner pays a fine $\tau$ that is exogenous and identical in both periods. ${ }^{31}$ The fine can be interpreted as a punishment for "failing the trust" of the public or the ruler.

${ }^{29}$ In reality, the share of output collected by the planner, $(1-\lambda)$, is not necessarily consumed by the planner himself; he probably collects only a portion thereof, $\alpha(1-\lambda)$. It can be thought of as a share of output that is confiscated by the state and is not redistributed back to managers in the form of some public goods. For example, it can be stolen by the ruler(s), wasted on supporting other dictators, and so on. For simplicity, we set $\alpha$ to 1 .

${ }^{30}$ This model abstracts from monitoring problems and corruption. Two possible types of problems could be: (i) managers producing high output do not surrender the adequate shares, an analogue of tax evasion, and, (ii) situation when high aggregate output is produced, but managers and the planner announce to the ruler that low aggregate output was produced, and split the difference.

${ }^{31}$ As discussed earlier, we believe that the assumption of a fixed fine corresponds well to the reality. Fines are generally fixed in nominal terms and adjusted infrequently. In planned economies, the fine was neither increasing in time nor fixed as a ratio to total output and, in determining the size of the fine, the planner was limited by political-economy constraints. Hypothetically, two types of fine are possible: (i) for setting low targets, corresponding to our $\tau$, and (ii) for not meeting the plan $(\hat{Y}<\bar{Y})$. In our model, however, the planner knows the expected/aggregate output under each incentive scheme and chooses a plan compatible with the incentive scheme. Thus the plan is always met, barring a sudden shock to the distribution $\phi$, and this type of fine never needs to be paid. Indeed, the planning literature provides evidence that the latter type of fine was rarely implemented-the plan seemed to have been met always. 


\section{B. Definition and Characterization of Equilibrium}

\section{Definition}

The equilibrium in this model is defined as the allocation of consumption and managers, and a set of payoffs to managers such that: (i) taking the set of payoffs as given, managers choose how much effort, $x_{t}$, to put into production in order to maximize their utility of consumption, (ii) knowing the behavior of managers, the planner chooses each period the set of payoffs, $\lambda_{t}$ to maximize his utility, and (iii) the markets for managers and products clear.

By solving the managers' maximization problem (see Appendix II for its full description), we find that high effort $(x=1)$ is the optimal choice if

$$
\lambda_{t}\left(\phi_{H}-\phi_{L}\right) \varepsilon \geq \gamma
$$

In other words, high effort is optimal only if the marginal benefit of higher consumption from the extra effort, $\lambda\left(\phi_{H}-\phi_{L}\right) \varepsilon$, exceeds the marginal cost of that effort, $\gamma$.

The planner's optimization problem is similar to that of managers, however, he chooses $\lambda$, taking behavior of managers, described by (3), as given. In choosing $\lambda$, the planner's choices are twofold. In the option 1, the planner can select the smallest share of output that would stimulate managers to achieve high-effort output, $\lambda_{H}$, that is,

$$
\lambda_{H}=\frac{\gamma}{\left(\phi_{H}-\phi_{L}\right) \varepsilon},
$$

On the one hand, on the aggregate level, this would lead to achieving the potential output in both periods. On the other hand, the planner gets a smaller share of a bigger pie: the aggregate output is higher, but the planner leaves a bigger share of it to managers. ${ }^{32}$

In the option 2, the planner can select the lowest share of output going to managers that will guarantee just their minimum consumption, $\lambda_{\min (t)}$, offering low-effort incentives. As a result, the planner gets a larger share of a smaller pie:

$$
\lambda_{\min (t)}=\frac{c_{\min }-w^{M}+\gamma}{z_{L(t)}}
$$

${ }^{32}$ In case when condition (4) would not guarantee minimum consumption of the managers, $\lambda_{H}$ would become $\lambda_{H(t)}=\frac{c_{\min }-w^{M}+\gamma}{z_{L(t)}}$. 
How would the planner decide? Obviously, the planner will provide high-effort incentives (an option 1) if the loss of share of output to the planner caused by higher $\lambda$ is compensated for by a higher aggregate output. Formally, the following must be true in period $t$ for the planner to choose the high-effort option 1 :

$$
\left(1-\lambda_{H}\right) Y_{H(t)} \geq\left(1-\lambda_{\min (t)}\right) Y_{L(t)}-\tau,
$$

where $Y_{H(t)}=\phi_{H} z_{H(t)}+\left(1-\phi_{H}\right) z_{L(t)}$ and $Y_{L(t)}=\phi_{L} z_{H(t)}+\left(1-\phi_{L}\right) z_{L(t)}$.

The model is closed, with two market clearing conditions. The first condition states that in both periods, the aggregate consumption equals the aggregate endowments and net production (see Appendix II). The second condition states that the sum of managers producing high output, $m_{H}$, and managers producing low output, $m_{L}$, equals the total supply of managers, where $m_{H(t)}=\phi_{H}$ if $x_{t}=1$, and $m_{H(t)}=\phi_{L}$ if $x_{t}=0$. Formally,

$$
m_{H(t)}+m_{L(t)}=1 \text {. }
$$

\section{Characterization}

It follows from (6) that in each period, the planner provides high-effort incentives and announces an output plan consistent with those incentives if and only if the fine for the low output is bigger than the difference between the planner's shares of output under low effort and high effort: ${ }^{33}$

$$
\tau \geq \lambda_{H} Y_{H(t)}-\lambda_{\min (t)} Y_{L(t)}-\left(\phi_{H}-\phi_{L}\right) \varepsilon
$$

In this model, three output outcomes can occur in equilibrium: (i) high aggregate output is produced in both periods, $(\mathrm{H}, \mathrm{H})$; (ii) low aggregate output is produced in both periods, (L, L); or (iii) high aggregate output is produced in the first period, but low aggregate output is produced in the second period, $(\mathrm{H}, \mathrm{L}) .{ }^{34}$ Not only are all three types of outcomes feasible, but all three strategies are rational and time consistent. These outcomes depend on the parameters of the model and, consequently, on the shares of output that the planner offers to the managers. While the $(\mathrm{H}, \mathrm{H})$ outcome has been, of course, the goal of planning, we pay special attention to the outcome in which the managers reduce their effort in the second period, $(\mathrm{H}, \mathrm{L})$.

${ }^{33}$ Hypothetically, under perfect foresight, the fine, $\tau$, can be set high enough to always satisfy the high-effort condition. Alternatively, $\tau$ can be interpreted as a lump sum tax. However, as we discussed earlier, the range of permissible $\tau$ is restricted.

${ }^{34}$ It can be shown that a combination of low-effort incentives in the first period and higheffort incentives in the second one is not an equilibrium outcome. 
The case of high aggregate output in the first period and low aggregate output in the second period seems to be relevant for explaining the growth slowdown that has occurred in the centrally planned economies. Under this scenario, the planner is more concerned about expanding his output share than expanding output itself. The following condition must hold:

$$
\lambda_{H} Y_{H(1)}-\lambda_{\min (1)} Y_{L(1)} \leq \tau+\varepsilon\left(\phi_{H}-\phi_{L}\right)<\lambda_{H} Y_{H(2)}-\lambda_{\min (2)} Y_{L(2)}, \ldots
$$

that is, the low-output fine is larger (smaller) than the difference between the planner's share of high-effort and low-effort output in the first (second) period.

What is the driving force behind this switching of effort/output from high to low? It is reasonable to assume that most planned economies started with high-effort incentives. Planning was generally introduced in a postwar period, in economies near collapse and riddled with inflation and unemployment. Reservation consumption was low as wages were near the subsistence level, and marginally higher effort yielded visible improvement in consumption. In the two decades that followed the introduction of planning the average living standard improved substantially and the managers had to weight the benefits of additional effort against the foregone leisure.

In our model aggregate output $(Y)$ and its share to be allocated to managers $(\lambda)$ are functions of technological progress, $\varepsilon$. Technological progress may increase $Y$ and decrease $\lambda_{\min }$ enough for the increment in the planner's share of output to exceed the fine - associated with low-effort output and the following inequality would be true: $\left(1-\lambda_{H}\right) Y_{H(t)}<\left(1-\lambda_{\min }\right) Y_{L(t)}-\tau$. In other words, in the second period, the high-effort share of output allocated to the managers may be too high and not enough would be left for the planner (or the state) to confiscate. ${ }^{35}$ If we would allow changes in other parameters of the model, a similar impact would have an increase in the managers' endowment, $w^{M}$, a decrease in the minimum consumption, $c_{\min }$, or an exogenous decrease in $\gamma^{36}$

${ }^{35}$ These results imply an intuitive conclusion: as long as the planner is set to confiscate large portions of output, managers would opt for a low-effort equilibrium. If $\lambda_{H}$ is close to one, then the state confiscates and redistributes very little of the aggregate output and the economy would start resembling a market system.

${ }^{36}$ By focusing on production and consumption of a single good, our model does not capture one important feature of bureaucratic economies decline: constructing/implementing a plan for production of consumption goods is more complex than constructing/implementing a plan for production of capital goods. Most bureaucratic economies experience persistent shortages of consumption goods and, hence, the absolute decrease in the minimum consumption could be interpreted as "satiation with one available type of consumption good." While, at the later stages of the central planning, the CEE countries attempted to solve the problem of the lack of consumption goods by shifting targets from production to sales, the same incentive problem outlined in our "production" model would apply to sales targets. 


\section{Welfare Analysis}

Finally, we examine the welfare implications of the high-effort and low-effort equilibrium mix. We compare it to the optimal solution, which is derived by maximizing the aggregate consumption subject to feasibility constraints, see Appendix II. It follows that high effort is optimal if the following condition below is satisfied in both periods:

$$
\frac{\gamma}{\left(\phi_{H}-\phi_{L}\right) \varepsilon} \leq 1
$$

Two observations regarding the optimality of the equilibrium solution can be made. First, the above condition is identical to a situation where the managers get the entire output, that is, $\lambda=1$. Hence, we find a range of parameters, where high effort would be the optimal solution, but managers put in low effort, specifically, $\lambda\left(\phi_{H}-\phi_{L}\right) \varepsilon<\gamma \leq\left(\phi_{H}-\phi_{L}\right) \varepsilon$

(Figure 2). This is the result of managers receiving only a fraction $\lambda$ of additional output while internalizing all the cost of additional effort, $\gamma$, which may be-from the welfare point of view-much smaller than the aggregate gain in output.

Figure 2. Cost of Effort-Output Relationship

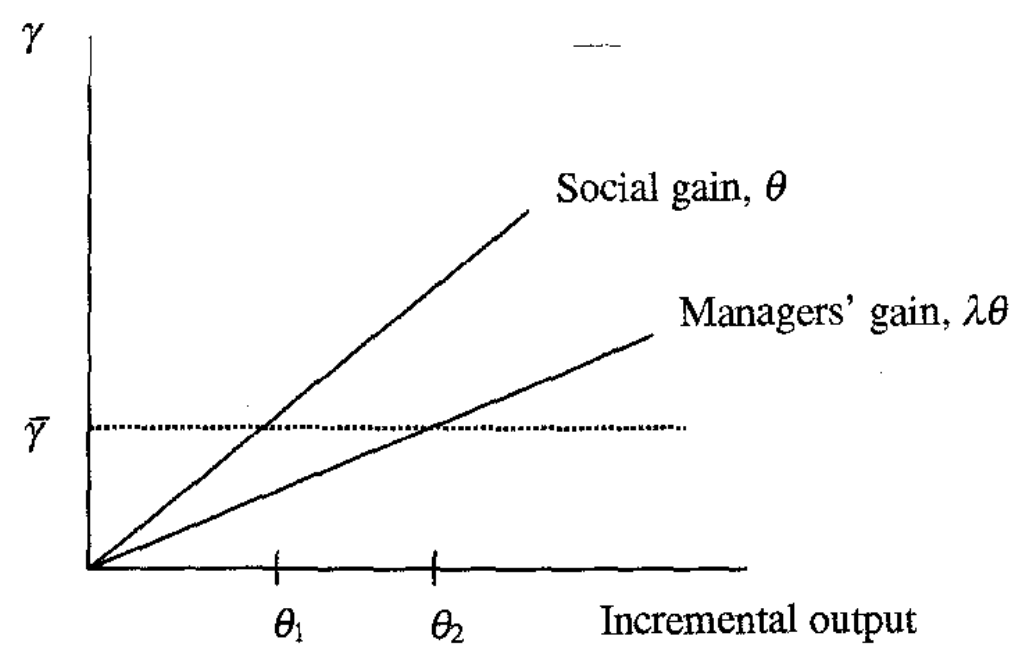

Notes: $\theta=\left(\phi_{H}-\phi_{L}\right) \varepsilon$. For $\theta<\theta_{1}$, the cost of high effort, $\bar{\gamma}$, is larger than both the social gain of the incremental, high-effort output $\left(\phi_{H}-\phi_{L}\right) \varepsilon$ and the share that goes to the managers, $\lambda\left(\phi_{H}-\phi_{L}\right) \varepsilon$. Similarly, for $\theta>\theta_{2}, \gamma$ is smaller than both the social and managers' gain. However, for $\theta_{1} \leq \theta \leq \theta_{2}$, the social gain is larger than $\gamma$ but smaller than the managers' gain. 
Second, since the condition (10) is identical in both periods, the effort must be also identical in both periods in the optimum, and hence the high-low equilibrium cannot be an optimal, output-maximizing solution. More specifically, in the $(H, L)$ equilibrium, the following condition holds: $\lambda_{2}\left(\phi_{H}-\phi_{L}\right) \varepsilon<\gamma \leq \lambda_{1}\left(\phi_{H}-\phi_{L}\right) \varepsilon \leq\left(\phi_{H}-\phi_{L}\right) \varepsilon$, where $\lambda_{t}$ is the share of output going to the managers at period $t$. While high effort is an optimal solution in both periods, given the share of output in period $2\left(\lambda_{2}\right)$, the managers put low effort into the production during that period.

\section{Policy Implications}

Based on our model, the two main conclusions regarding behavior of the planner in bureaucratically organized economies can be made. First, and perhaps most important, unless a sufficiently high penalty for offering low-effort incentives is available, output targets would be bad for growth in the long run. Second, as long as the planner follows his own utility function, that is, maximizes his own consumption, he may not be interested in formulating the socially optimal plan.

A few technical points are also worth summarizing. First, the high effort necessary for sustainable growth is generated only by the allocation of sufficiently large shares of output to managers. If either the managers' "reservation consumption" goes down or the planner wants to keep more of the output for himself (or for the state), the economy may end up in the low-effort equilibrium in the second period. Second, the planner-as long as the punishment for selecting the "soft" plan is sufficiently light-may opt for a socially suboptimal plan if he can keep a larger share of smaller output for himself. Finally, other things being equal, the economy is likely to switch from a high-effort outcome in the first period to a low-effort outcome in the second period, provided the technological progress has been sufficiently strong to satisfy the managers' reservation consumption, even at low-effort output.

All results seem to be borne out by the empirical evidence from the CEE countries. First, not only was the state redistributing an increasingly bigger share of output, but more and more of this redistribution was wasteful, such as the expenditures on Communist Party offices, defense spending, subsidies to loss-making firms, and so on. Second, the punishment for underperformance declined over time. As the bureaucratic structures became entrenched, those planners/managers that were members of the elite had increasing job and personal emoluments security.

We generalize that output targets-in any bureaucratically organized economy--are likely to have a medium- to long-term adverse impact on economic performance as long as the planner tries to confiscate a large share of output and the planner's punishment for underperformance vis-à-vis potential output is fixed over time. The implications of our model are straightforward: under the above conditions, bureaucratically organized economies are destined to endure gradually declining growth rates irrespective of the nature of macroeconomic shocks. Although, at least hypothetically, the ruler could ensure high-effort plans by fine-tuning the value of the punishment, reality suggests that there are limits to this option. 


\section{Conclusions}

Bureaucratically organized economic structures are usually less efficient than structures (economies) in which agents are free to choose their output targets as well as the means to meet them. Historically, market economies have outperformed command ones by a wide margin. However, economists agree relatively little on what is the main source of this difference. In this paper we provide a complementary model to the mainstream explanations in the literature, and we argue that the main cause of the mediocre performance of bureaucratic economic systems follows from the very nature of the contract between the planner and the managers.

Drawing on the available empirical evidence, we model a bureaucratic system in which the planner, under certain conditions, has strong incentives not to choose the ambitious plan. In particular, these conditions include sufficiently strong technological progress, an increase in the managers' reservation consumption, or a lack of sufficiently high penalty imposed on a planner for designing an incentive scheme leading to low output. In a future research, an interesting extension would be to incorporate monitoring problems and corruption explicitly to the model. 


\section{Econometric Tests of Growth Comovements AMONG THE CEE CounTries}

In this Appendix, we present some simple econometric tests, results of which support our stylized facts regarding the rates of growth and comovements in the CEE countries in Section $\amalg$. First, we describe the origin of the data. Second, we test for nonstationarity and a trend in the series, and find that growth rates had unit roots and statistically significant negative trends. Third, we test for co-integrating relationships, both in a panel setting and in two-country regressions, and find that their rates of growth were cointegrated.

\section{A. Data Issues}

In our regressions, we use the net material product (NMP) data in fixed prices as published by the United Nations Statistical Office for the pre-1970 period and the data from the World Bank (1993) thereafter. The series are available for Bulgaria (1949-89), Czechoslovakia (1949-89), the German Democratic Republic (1951-89), Hungary (1949-89), Poland (1949-89), Romania (1952-89), Yugoslavia (1953-88), and the U.S.S.R. (1949-89).

We are leaving aside three well-documented issues. First, the authorities in the CEE countries may have regularly overestimated real output figures. Havlik (1983) calculated that the true real rate of growth of NMP was on average lower by some 1-2 percentage points than that published officially, owing to improperly estimated price indices. However, there is no evidence that this bias was more prevalent in the 1950s than, say, in the 1980s, a conclusion at which Leamer and Taylor (1999) seem to have arrived as well. Second, NMP is a narrower concept than GDP: only partial account is taken of tertiary services, and no account is taken of household production, the informal economy, and so on. As in the previous case, there is little evidence that the impact of this omission on the rate of growth would be more pronounced in certain periods than in others. Third, and perhaps most fundamentally, the comparisons of GDP and NMP in market and planned economies, respectively, obfuscate the fundamental difference between these two systems. Under the plan, firms could - for a period of time much longer than in a market economy-produce goods and services that nobody demanded. Moreover, firms used to produce goods that would not have been demanded had products from a market economy been available. As a crude measure of these effects, the ratio of total inventories as percentage of net material product increased in Czechoslovakia between 1954 and 1989 from 32 percent to 90 percent, respectively (see Federální Ministerstvo Financí, 1990).

\section{B. Integration}

Before modeling time series, it is useful to determine the orders of integration for the variables considered. The visual observation of the NMP time series for the eight CEE countries suggests that these growth rates declined over time and that presumably both negative trends and unit roots were present. See Figure 3 that shows both the raw series and series filtered by the Hodrick-Prescott filter. 
Figure 3. Selected Countries: Net Material Product, 1949-89 1/

(Annual percentage change)
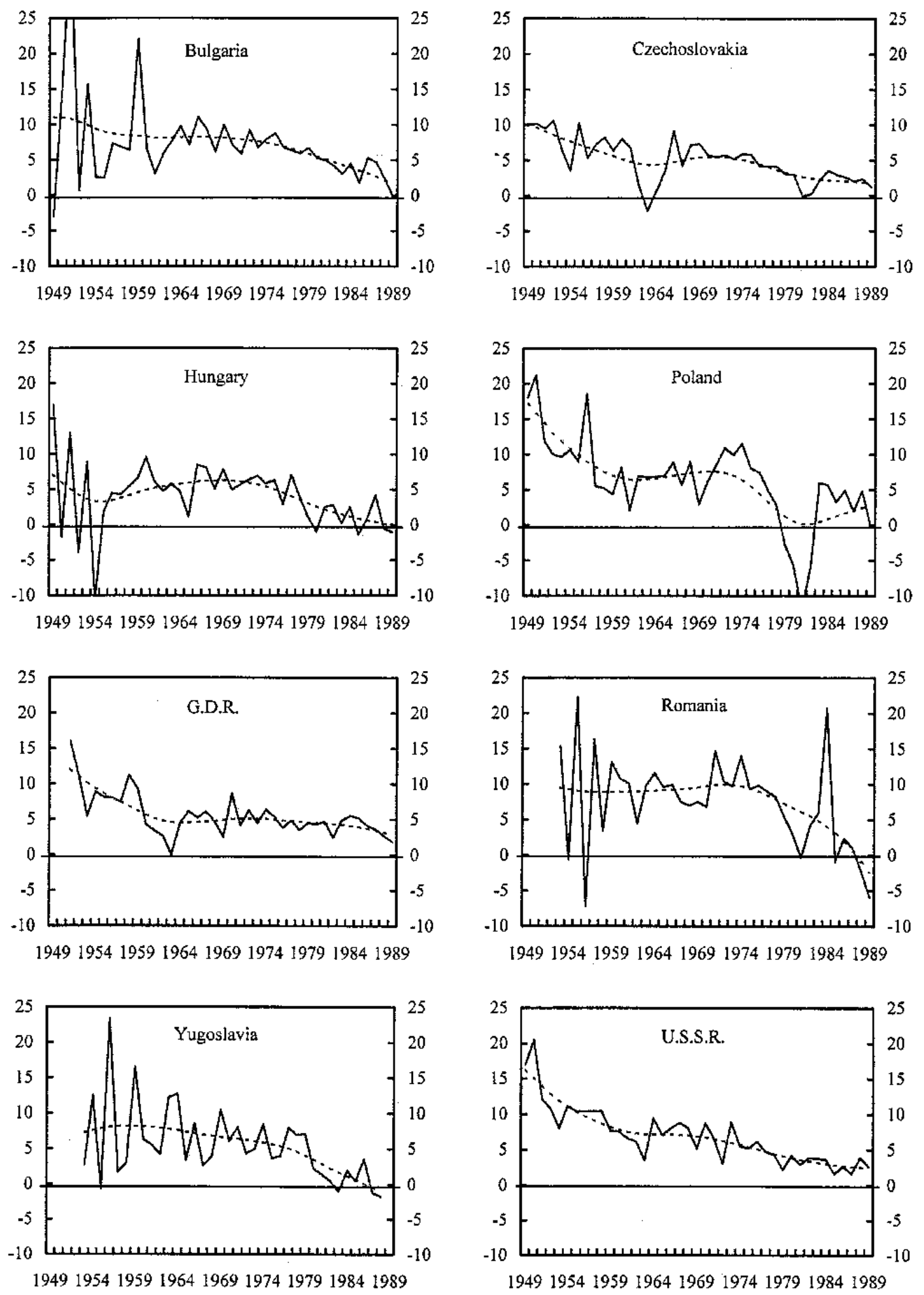

Source: United Nations, World Bank; authors calculations. 1/ Raw data and the Hodrick-Prescott filter. 
We test formally first for the presence of a trend by running an AR(1) auto-regression with a linear trend. We find that most series contain a negative and statistically significant linear trend at the 95 percent significance level when the full sample period is used (Table A1). The rate of growth seems to have declined by some $0.1-0.2$ percentage point per annum in most countries. The only exception is Hungary: in the full sample, the trend appears to be insignificant, albeit negative. This is, however, a result of large growth swings at the beginning of the sample period after Hungary was invaded by the Soviet Army. When the sample period is shortened to $1958-89$, the negative trend becomes highly significant.

The above results confirm that our variables are negatively trended and determine also the choice of the proper specification of the unit root tests, that is, the augmented Dickey-Fuller statistics (ADF) with an intercept and a linear trend. Table A2 lists the first-order ADF statistics ${ }^{37}$ for the series in levels and in first differences. The application of the ADF tests is appropriate since the time series exhibit no structural breaks when tested for in recursive regressions of the rate of growth on its lagged values.

Our results indicate that, in the full sample, the null hypothesis of no unit roots can be rejected in five out of eight countries. On inspection, however, the three countries where the hypothesis cannot be rejected (Bulgaria, Yugoslavia, and the U.S.S.R.) had excessively volatile output growth in the early $1950 \mathrm{~s}$, as compared to the rest of the sample.$^{38}$ When their respective samples are shortened to 1962-89, 1966-88, and 1956-89, the hypothesis of no unit roots can be rejected. Hence, with the usual caveats, we will treat all series as nonstationary. Our findings also imply that the time series of NMP in levels are integrated of order two, $\mathrm{I}(2)$, as opposed to the standard finding of growth rate stationarity in market economies.

\section{Co-Integration}

Co-integration analysis helps clarify the long-run relationship between two or more integrated variables. Two co-integrating relationships are tested: a panel co-integration and pairwise co-integration. We employ the maximum likelihood procedure for finite-order vector autoregressions (VARs) developed by Johansen and Juselius (1990). Empirically, the lag of the VAR is not known a priori but has to be established. In estimating an unrestricted VAR with all countries included, both the Akaike and Schwarz information criteria point to a first-order specification.

First, we test for the presence of a co-integrating relationship in a panel setting. At least one co-integrating vector was found in every regression containing either all eight $\mathrm{CEE}$ countries or any subsamples thereof (Table A3). Indeed, the rates of growth of NMP of the

${ }^{37}$ Both the Akaike and Schwartz information criteria point to a first-order specification for the $\mathrm{ADF}$ tests (we do not list these results here).

${ }^{38}$ As is common in small-sample data sets, the power of the ADF test is low: exclusion of a few observations can change significantly the value of the ADF statistics. 
CEE countries have been co-integrated, that is, the rates of growth of this group(s) of countries moved together. Although we present only six subsamples, the results change only marginally in the remaining combinations of countries.

The panel co-integration tests provide generally weaker evidence than the pairwise co-integration tests. Hence, we perform the same tests for all pairs of countries in our sample (Table A4). Again, the hypothesis of a co-integrating relationship between the rates of growth of the individual CEE countries cannot be rejected for any of the pairs. Most pairs seem to suggest the existence of two co-integrating relationships.

To summarize, although the hypotheses reviewed in Section I.B could be used to explain the negative trend in the series, none of them conjectured the growth pattern observed here. We find it difficult to explain the observed growth similarities, given the different initial levels of development and/or the diverse structure of their economies. This growth pattern suggests that all countries in our sample were subject to the same process which gradually eroded their production capacity.

\section{Was the Common Cycle Caused by the Fluctuations in the Soviet Rate of Growth?}

The presence of a negative linear trend and co-integration do not prove, of course, our hypothesis that the growth slowdown was the result of planner-manager contracts, even though the growth slowdown was remarkably similar across the otherwise heterogeneous sample of the CEE countries. The growth similarity would point, however, to yet another explanation (observational equivalence): the $\mathrm{CEE}$ growth rates may have been driven by the developments in the largest economy in the sample-the U.S.S.R. This country was the largest trading partner of all the CEE countries (with the exception of Yugoslavia and Romania), and its growth swings may have affected the rates of growth in the other CEE economies. Is this hypothesis borne out by the evidence?

We find that cyclical fluctuations of Soviet output are not correlated with cyclical output fluctuations of the other CEE countries (Table 3). Specifically, the correlation coefficient is close to 0.5 only in the German Democratic Republic-U.S.S.R. case and around 0.2 in the case of Czechoslovakia and Poland. The correlation coefficient is around -0.2 in the case of Bulgaria and Hungary and close to zero in the case of Romania and Yugoslavia. In general, the pattern of correlation is more systematic among the individual CEE countries. For example, Czechoslovakia's cyclical fluctuations appear to be positively correlated with all countries, except Yugoslavia; Poland has positive, albeit low correlation coefficients with all countries, except Bulgaria; and the German Democratic Republic's cycle appears to be independent from all countries, except Czechoslovakia and the U.S.S.R. The U.S.S.R.'s and Yugoslavia's growth rates appear to be negatively correlated with most other countries. As a result, we are inclined to reject the hypothesis that Soviet growth was driving the rate of growth in the other countries. 
Table A1. The Rate of Growth in the CEE Countries Has a Negative Trend ${ }^{39}$

\begin{tabular}{|c|c|c|}
\hline $\begin{array}{l}\text { Country } \\
\text { Period }\end{array}$ & $\begin{array}{l}\text { Coefficient of a Linear Trend } \\
\text { (Standard errors) }\end{array}$ & $\begin{array}{l}\text { Probability of Rejecting } \\
\text { the Null Hypothesis of a } \\
\text { Linear Trend }\end{array}$ \\
\hline $\begin{array}{l}\text { Bulgaria } \\
\quad 1950-89\end{array}$ & $\begin{array}{r}-0.271 \\
(0.080)\end{array}$ & 0.002 \\
\hline $\begin{array}{l}\text { Czechoslovakia } \\
1950-89\end{array}$ & $\begin{array}{r}-0.091 \\
(0.039)\end{array}$ & 0.026 \\
\hline $\begin{array}{l}\text { German Democratic Republic } \\
\text { 1952-89 }\end{array}$ & $\begin{array}{l}-0.071 \\
(0.035)\end{array}$ & 0.050 \\
\hline $\begin{array}{l}\text { Hungary } \\
1950-89\end{array}$ & $\begin{array}{r}-0.082 \\
(0.059)\end{array}$ & 0.176 \\
\hline $1958-89$ & $\begin{array}{r}-0.195 \\
(0.054)\end{array}$ & 0.001 \\
\hline $\begin{array}{l}\text { Poland } \\
\quad 1950-89\end{array}$ & $\begin{array}{r}-0.135 \\
(0.072)\end{array}$ & 0.070 \\
\hline $\begin{array}{l}\text { Romania } \\
1955-89\end{array}$ & $\begin{array}{r}-0.258 \\
(1.011)\end{array}$ & 0.016 \\
\hline $\begin{array}{c}\text { Yugoslavia } \\
1954-88\end{array}$ & $\begin{array}{r}-0.364 \\
(0.079)\end{array}$ & 0.000 \\
\hline $\begin{array}{l}\text { U.S.S.R. } \\
1950-89\end{array}$ & $\begin{array}{r}-0.184 \\
(0.051)\end{array}$ & 0.001 \\
\hline
\end{tabular}

Source: Authors' calculations.

${ }^{39}$ An Ordinary Least Square (OLS) estimate of the growth rate on a constant, a linear trend, and the one-period lagged growth rate. 
Table A2. Growth Rates Are Nonstationary, from 1949 to 1989

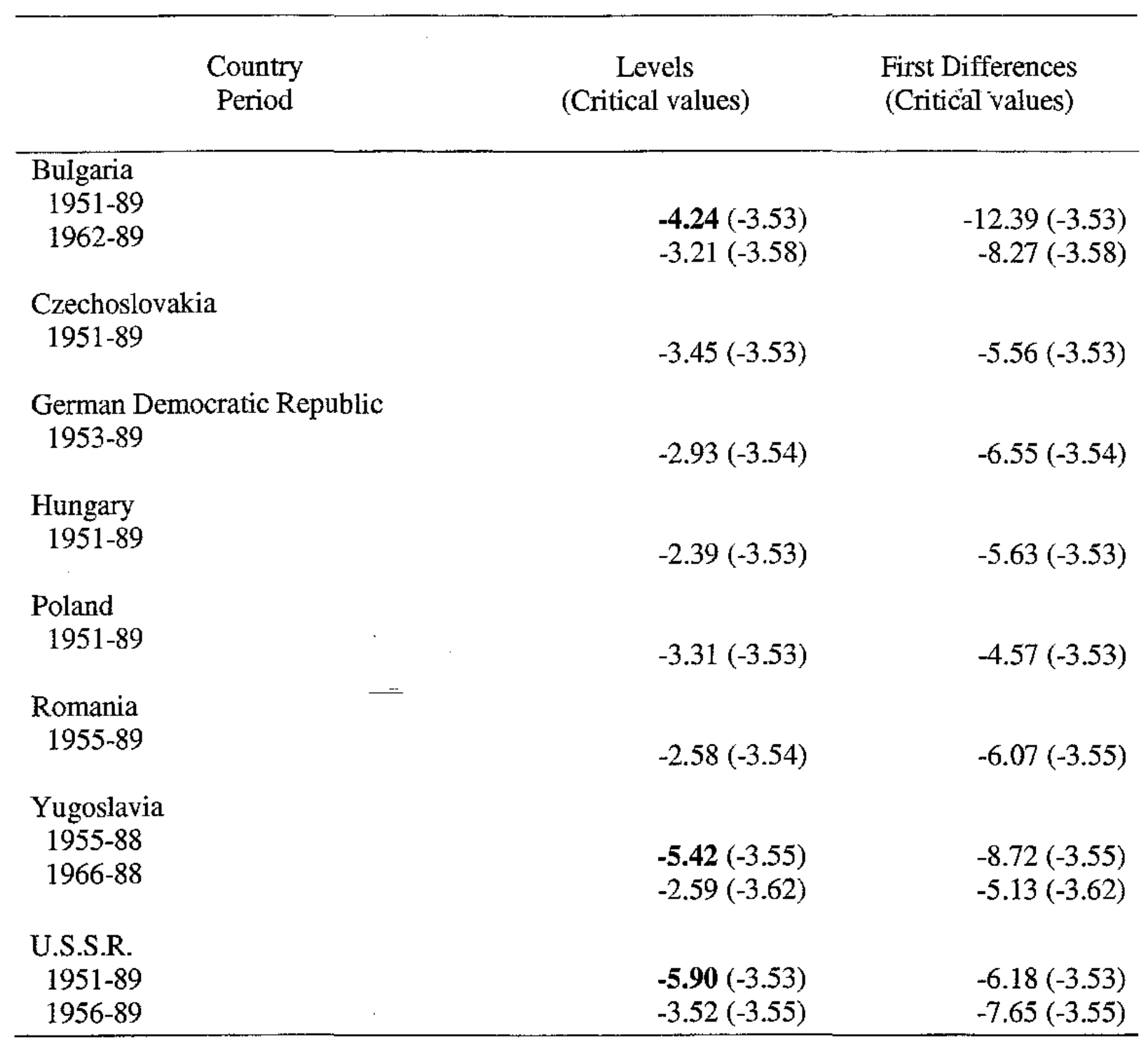

Source: Authors' calculations.

Note: The augmented Dickey-Fuller regressions include an intercept and a linear trend. Sample periods in which the null hypothesis of no unit roots cannot be rejected are indicated in bold. 
Table A3. Growth Rates Are Co-Integrated in a Panel Setting

\begin{tabular}{|c|c|c|c|}
\hline \multirow{2}{*}{ Countries Included in the Regression } & \multicolumn{2}{|c|}{ Hypotheses: } & \multirow{2}{*}{$\begin{array}{c}\text { Statistics } \\
\begin{array}{c}\text { Maximum.Eigenvalue } \\
\text { Trace }\end{array} \\
\end{array}$} \\
\hline & Null $A$ & Alternative & \\
\hline \multirow{3}{*}{$\begin{array}{l}\text { Bulgaria, Czechoslovakia, German } \\
\text { Democratic Republic, Hungary, Poland, } \\
\text { Romania, Yugoslavia, U.S.S.R. }\end{array}$} & $R=0$ & $R=1$ & $\begin{array}{r}73.50(54.17) \\
258.17(17488)\end{array}$ \\
\hline & $R \leq 1$ & $R=2$ & $\begin{array}{r}47.10(48.57) \\
184.66(140.02)\end{array}$ \\
\hline & $R \leq 2$ & $R=3$ & $\begin{array}{r}39.47(42.67) \\
137.57(109.18)\end{array}$ \\
\hline \multirow[t]{4}{*}{$\begin{array}{l}\text { Czechoslovakia, German Democratic } \\
\text { Republic, Hungary, Poland, U.S.S.R. }\end{array}$} & $R=0$ & $R=1$ & $\begin{array}{r}39.43(37.07) \\
124.01(82.23)\end{array}$ \\
\hline & $R \leq 1$ & $R=2$ & $\begin{array}{l}32.65(31.00) \\
84.58(58.93)\end{array}$ \\
\hline & $R \leq 2$ & $R=3$ & $\begin{array}{l}27.72(24.35) \\
51.93(39.33)\end{array}$ \\
\hline & $R \leq 3$ & $R=4$ & $\begin{array}{l}15.56(18.33) \\
24.20(23.83)\end{array}$ \\
\hline \multirow[t]{4}{*}{ Bulgaria, Romania, Yugoslavia, U.S.S.R. } & $R=0$ & $R=1$ & $\begin{array}{r}62.48(31.00) \\
136.95(58.93)\end{array}$ \\
\hline & $R \leq 1$ & $R=2$ & $\begin{array}{l}28.67(24.35) \\
74.47(39.33)\end{array}$ \\
\hline & $R \leq 2$ & $R=3$ & $\begin{array}{l}24.94(18.93) \\
45.80(23.83)\end{array}$ \\
\hline & $R \leq 3$ & $R=4$ & $\begin{array}{l}20.86(11.54) \\
20.86(11.54)\end{array}$ \\
\hline
\end{tabular}


Table A3. Growth Rates Are Co-Integrated in a Panel Setting (concluded)

\begin{tabular}{|c|c|c|c|}
\hline \multirow{2}{*}{ Countries Included in the Regression } & \multicolumn{2}{|c|}{ Hypotheses: } & \multirow{2}{*}{$\begin{array}{c}\text { Statistics } \\
\begin{array}{c}\text { Maximum Eigenvalue } \\
\text { Trace }\end{array} \\
\end{array}$} \\
\hline & Null A & Alternative & \\
\hline \multirow[t]{3}{*}{$\begin{array}{l}\text { Czechoslovakia, German Democratic } \\
\text { Republic, Hungary, Poland }\end{array}$} & $R=0$ & $R=1$ & $\begin{array}{rr}49.13 & (31.00) \\
105.03 & (58.93)\end{array}$ \\
\hline & $R \leq 1$ & $R=2$ & $\begin{array}{c}29.62(24.35) \\
55.80(39.33)\end{array}$ \\
\hline & $R \leq 2$ & $R=3$ & $\begin{array}{ll}\mathbf{1 6 . 5 3} & (18.33) \\
26.18 & (23.83)\end{array}$ \\
\hline \multirow[t]{3}{*}{ Bulgaria, Romania, Yugoslavia } & $R=0$ & $R=1$ & $\begin{array}{r}61.12(24.35) \\
110.82(39.33)\end{array}$ \\
\hline & $R \leq 1$ & $R=2$ & $\begin{array}{l}26.99(18.33) \\
49.70(23.83)\end{array}$ \\
\hline & $R \leq 2$ & $R=3$ & $\begin{array}{l}22.71(11.54) \\
22.71(11.54)\end{array}$ \\
\hline \multirow[t]{3}{*}{$\begin{array}{l}\text { German Democratic Republic, } \\
\text { Romania, Yugoslavia }\end{array}$} & $R=0$ & $R=1$ & $\begin{array}{l}61.14(24.35) \\
98.64(39.33)\end{array}$ \\
\hline & $R \leq 1$ & $R=2$ & $\begin{array}{l}24.66(18.33) \\
37.50(23.83)\end{array}$ \\
\hline & $R \leq 2$ & $R=3$ & $\begin{array}{l}12.84(11.54) \\
12.84(11.54)\end{array}$ \\
\hline
\end{tabular}

Source: Authors' calculations.

Notes: Regressions with one lag, unrestricted intercepts, and trends in the VAR. $R$ indicates the number of potential co-integrating vectors; the 95 percent critical values are in parentheses; and statistically insignificant results are indicated in bold. 
Table A4. Growth Rates Are Co-Integrated in Pairwise Tests of Co-Integration: Maximum Eigenvalue and Trace Tests

\begin{tabular}{|c|c|c|c|c|c|c|c|}
\hline & Czechoslovakia & $\begin{array}{c}\text { German Dem. } \\
\text { Rep. }\end{array}$ & Hungary & Poland & Romania & Yugoslavia & U.S.S.R. \\
\hline \multirow{2}{*}{ Bulgaria } & $43.09 ; 55.34$ & $61.72 ; 83.19$ & $37.80 ; 59.44$ & $36.58 ; 50.12$ & $39.02 ; 64.83$ & $48.57 ; 75.41$ & $49.45 ; 69.02$ \\
\hline & $12.25 ; 21.24$ & $21.47 ; 21.46$ & $21.64 ; 21.64$ & $13.53 ; 13.53$ & $25.81 ; 25.81$ & $26.84 ; 26.84$ & $19.57 ; 19.57$ \\
\hline \multirow{2}{*}{ Czechoslovakia } & & $33.11 ; 47.68$ & $43.16 ; 56.99$ & $19.82 ; 29.90$ & $40.22 ; 51.43$ & $44.25 ; 54.77$ & $26.30 ; 40.80$ \\
\hline & & $14.56 ; 14.56$ & $13.83 ; 13.83$ & $10.07 ; 10.07$ & $11.20 ; 11.20$ & $10.51 ; 10.51$ & $14.50 ; 14.50$ \\
\hline German Dem. & & & $33.06 ; 53.72$ & $21.35 ; 31.85$ & $40.28 ; 53.13$ & $44.68 ; 59.05$ & $31.72 ; 52.62$ \\
\hline Rep. & & & $20.66 ; 20.66$ & $10.50 ; 10.50$ & $12.85 ; 12.85$ & $14.38 ; 14.38$ & $20.90 ; 20.90$ \\
\hline \multirow{2}{*}{ Hungary } & & & & $42.35 ; 53.72$ & $38.92 ; 57.92$ & $49.86 ; 67.30$ & $41.76 ; 61.14$ \\
\hline & & & & $11.37 ; 11.37$ & $19.00 ; 19.00$ & $17.44 ; 17.44$ & $19.38 ; 19.38$ \\
\hline \multirow{2}{*}{ Poland } & & & & & $46.11 ; 53.96$ & $45.87 ; 53.80$ & $21.65 ; 33.17$ \\
\hline & & & & & $7.85 ; 7.85$ & $7.93 ; 7.93$ & $\cdot 11.53 ; 11.53$ \\
\hline \multirow{2}{*}{ Romania } & & & & & & $59.13 ; 83.15$ & $38.28 ; 64.45$ \\
\hline & & & & & & $24.02 ; 24.02$ & $26.17 ; 26.17$ \\
\hline \multirow{2}{*}{ Yugoslavia } & & & & & & & $44.61 ; 69.57$ \\
\hline & & & & & & & $24.95 ; 24.95$ \\
\hline
\end{tabular}

Source: Authors' calculations.

Notes: Regressions with one lag, unrestricted intercepts, and trends in the VAR; results for one and two co-integrating relationships. The first row of each cell lists the maximum eigenvalue and trace tests for the null hypothesis that the number of co-integrating relationships is equal to nil and the alternative hypothesis is equal to one; the second row lists the same tests for the null hypothesis that the number of co-

integrating relationships is equal to one and the alternative hypothesis is equal to two. The 95 percent critical values for these tests are 18.33, $23.83,11.54$, and 11.54 , respectively. Statistically insignificant results are indicated in bold. 


\section{DEFINITION OF EQULIBRIUM}

The manager's optimization problem in each period $t,(t=1,2)$ can be described as follows. By choosing consumption, $c_{t}^{M}$ and effort, $x_{t}$, the manager solves, taking.the offered share of output, $\lambda_{t}$, as given:

$\max _{c, x \in\{0,1\}} c_{t}^{M}$,

subject to

$c_{t}^{M}+\chi_{t} \leq w^{M}+\lambda_{t}\left\{x_{t}\left[\phi_{H} z_{H(t)}+\left(1-\phi_{H}\right) z_{L(t)}\right]+\left(1-x_{t}\right)\left[\phi_{L} z_{H(t)}+\left(1-\phi_{L}\right) z_{L(t)}\right]\right\}$

and $c_{t}^{M} \geq 0$.

The planner's optimization problem is similar. However, he chooses his consumption, $c_{t}^{P}$ and $\lambda_{t}$, taking the behavior of managers as given:

$\max _{c, \lambda} c_{t}^{P}$

subject to

$c_{t}^{P} \leq w^{p}+\left(1-\lambda_{t}\right) x_{t}\left[\phi_{H} z_{H(t)}+\left(1-\phi_{H}\right) z_{L(t)}\right]+\left(1-\lambda_{t}\right)\left\{\left\{\left(1-x_{i}\right)\left[\phi_{L} z_{H(t)}+\left(1-\phi_{L}\right) z_{L(t)}\right]\right\}-\tau\right\}$

and subject to manager's condition on minimum consumption: $c_{t}^{M} \geq c_{\min }$.

The model is closed with two market clearing conditions. The first condition states that, in each period, the aggregate consumption is (less or) equal to the aggregate endowments and net production:

$c_{t}^{P}+c_{t}^{M}+\chi_{t} \leq w^{M}+w^{P}+x_{t}\left[\phi_{H} z_{H(t)}+\left(1-\phi_{H}\right) z_{L(t)}\right]+\left(1-x_{t}\right)\left[\phi_{L} z_{H(t)}+\left(1-\phi_{L}\right) z_{L(t)}-\tau\right]$.

Second, the market clearing condition for managers is:

$m_{H(t)}+m_{L(t)} \leq 1, t=1,2$,

where $m_{H(t)}=\phi_{H}$ if $x_{t}=1$, and $m_{H(t)}=\phi_{L}$ if $x_{t}=0$. 


\section{REFERENCES}

Adam, Jan, 1989, Economic Reforms in the Soviet Union and Eastem Europe Since the 1960s, (London: Macmillan Press).

Alexeev, Michael, 1991, "The 'Storming' Pattern of Enterprise Behavior in a Centrally Planned Economy," The Journal of Economic Behavior and Organization, Vol. 15, (March), pp. 173-83.

Arrow, Kenneth J., and Leonid Hurwicz, 1960, "Decentralization and Computation in Resource Allocation," in: Essays in Economics and Econometrics: A Volume in Honor of Harold Hotelling, ed. by R.W. Pfouts, (Chapel Hill, North Carolina: University of North Carolina Press).

Banerjee, Abhijit V., and Michael Spagat, 1992, "Shortages Amid Plenty Under Soviet-Type Planning: A Theory of Unreliable Supplies," Journal of Comparative Economics, Vol. 16 (June), pp. 302-8.

Baron, David P., and David Besanko, 1984, "Regulation and Information in a Continuing Relationship," Information Economics and Policy, Vol. 1 (No. 3), pp. 267-302.

Brada, Josef C., 1978, "Plan Execution and the Workability of Soviet Planning," Joumal of Comparative Economics, Vol. 2 (March), pp. 65-9.

, 1989, "Technological Progress and Factor Utilization in Eastern European Economic Growth," Economica, Vol. 56 (November), pp. 433-48.

Bulíř, Aleš, 1995, "Credit Redistribution and Monetary Targets Under Central Planning in Czechoslovakia," Economic Systems, Vol. 19 (December), pp. 305-29. , 1998, "Business Cycle in Czechoslovakia Under Central Planning: Were Credit Shocks Causing It?" Journal of Comparative Economics, Vol. 26 (June), pp.226-45.

Crafts, Nicholas, 1999, "East Asian Growth Before and After the Crisis" Staff Papers, International Monetary Fund, Vol. 46, No. 2 (June), pp.139-66.

Dlouhý, Vladimír, 1990, "An Equilibrium Alternative to a Permanent Shortage," European Economic Review, Vol. 34 (May), pp. 340-48.

Easterly, William, and Stanley Fischer, 1995, "The Soviet Economic Decline," World Bank Economic Review, Vol. 9 (September), pp. 341-71.

Easterly, William, and Ross Levine, 1998, "Troubles with the Neighbours: Africa's Problem, Africa's Opportunity," Journal of African Economies, Vol.7 (March), pp.120-42.

Ellman, Michael, 1990, "Socialist Planning," in: Problems of the Planned Economy, ed. By John Eatwell, Murray Milgate, and Peter Newman (New York: W.W. Norton \& Co). 
Faith, Roger L., and Nancy C. Short, 1995, "Bureaucratic Tenure and Economic Performance in Centrally Planned Economies," Public Choice, Vol. 83 (April), pp. 139-57.

Federální ministerstvo financí, 1990, Dlouhodobý vývoj finančnich ukazatelü ČSFR do roku 1989, (Praha: Federální ministerstvo financí).

Freixas, Xavier, Roger Guesnerie, and Jean Tirole, 1985, "Planning Under Incomplete Information and the Ratchet Effect," Review of Economic Studies, Vol. 52 (April), pp.173-91.

Frimpong-Ansah, Jonathan, 1991, The Vampire State in Africa: The Political Economy of Decline in Ghana, (London: James Currey).

Havlik, Peter, 1983, "A Comparison of Purchasing Power Parity and Consumption Level in Austria and Czechoslovakia," Wiener Institut für Internationale Wirtschaftsvergleiche. Forschungsberichte, No. 87, (Vienna: Wiener Institut für Internationale Wirtschaftsvergleiche. Forschungsberichte)

Hayek, Friedrich A. von, 1940, "Socialist Calculation: The Competitive 'Solution'," Economica, Vol. 7 (May), pp.125-49.

Hernández-Catá, Ernesto, 2000, "The Fall and Recovery of the Cuban Economy in the 1990s: Mirage or Reality?" IMF Working Paper (forthcoming).

Hlaváček, Jiří, 1990, "Producers' Criteria in a Centrally Planned Economy," in: Optimal Decisions in Markets and Planned Economies, ed. by Richard E. Quandt and Dušan Tř́ska, (Boulder, Colorado: Westview Press), pp. 41-52.

Hunter, Holland, 1961, "Optimal Tautness in Developmental Planning," Economic Development and Cultural Change, Vol. 9 (July), pp. 561-72.

Hurwicz, Leonid, 1973, "The Design of Mechanisms for Resource Allocation," American Economic Review, Papers and Proceedings, Vol. 63 (May), pp. 1-30.

Ickes , Barry W., 1990a, "Do Socialist Countries Suffer a Common Business Cycle?" Review of Economics and Statistics, Vol. 72 (August), pp. 397-405.

Ickes, Barry W., 1990b, "The Theory of the Firm Under Capitalism and Socialism," in Optimal Decisions in Markets and Planned Economies, ed. by Richard E. Quandt and Dušan Tř́ska, (Boulder Colorado: Westview Press), pp. 10-26.

Johansen, Soren, and Katerina Juselius, 1990, "Maximum Likelihood Estimation and Inference on Cointegration, with Applications to the Demand for Money," Oxford Bulletin of Economics and Statistics, Vol.52 (May), pp. 169-210. 
Keren, Michael, 1982, "The Ministry, Plan Changes, and the Ratchet in Planning," Journal of Comparative Economics, Vol. 6 (December), pp. 327-42.

, 1991, "Single Dimensional Linear and Forcing Contracts: Did Targets and Bonuses Cause the Collapse of the Soviet Economy?" Economic Systems, Vol.15 (April), pp.19-41.

, 1993, "Optimal Tautness and the Economics of Incentives in Bureaucracies," Comparative Economic Studies, Vol. 35, (Spring), pp. 85-117.

Klacek, Jan and Alena Nešporová, 1984, "Economic Growth in CzechoslovakiaApplication of the CES Production Function," Czechoslovak Economic Papers, Vol. 22, pp. 83-100.

Kornai, János, 1980, The Economics of Shortage, (Amsterdam: North-Holland).

Landau, Daniel, 1994, "Impact of Military Expenditures on Economic Growth in the Less Developed Countries," Defence and Peace Economics, Vol. 5 (No. 3), pp.205-20.

Lange, Oskar, and Fred M. Taylor, 1938, On the Economic Theory of Socialism, ed. by Benjamin E. Lippincott (Minneapolis, Minnesota: The University of Minnesota Press).

Leamer, Edward E., and Mark P. Taylor, 1999, "Estimating Growth Equations for Previously Centrally Planned Economies: Dealing with Dubious Data and Disparate Information," Journal of Macroeconomies, Vol. 21 (Fall), pp. 639-71.

Majcher, Milan and Josef Valach, 1988, Financie podnikov a odvetví, (Bratislava: Vysoká škola ekonomická).

Malinvaud, Edmond, 1967, "Decentralized Procedures for Planning," in Activity Analysis in the Theory of Growth and Planning, ed. by M.O.L. Bacharach and E. Malinvaud (London: Macmillan.)

Marrese, Michael and Jan Vaňous, 1983, "Unconventional Gains from Trade," Journal of Comparative Economics, Vol. 7 (December), pp. 382-99.

Milanovic, Branko, 1994, "Determinants of Cross-Country Income Inequality: An 'Augmented' Kuznets' Hypothesis, " World Bank Policy Research Working Paper, No. 1246 (Washington: World Bank).

MlCoch, Lubomir, 1990a, "Behavior of the Czechoslovak Enterprise Sector", Research Paper No. 384 (Prague: Economic Institute of the Czechoslovak Academy of Sciences). , 1990b, "Syntéza deskriptivních analýz tradičního modelu, Politická ekonomie, Vol. 37 (July and August), pp. 769-86 and 925-38. 
Murrell, Peter, and Mancur Olson, 1991, "The Devolution of Centrally Planned Economies," Journal of Comparative Economics, Vol. 15 (June), pp. 239-65.

Ofer, Gur, 1987, "Soviet Economic Growth: 1928-1985," Joumal of Economic Literature, Vol. 25 (December), pp. 1767-833.

Olson, Mancur, 2000, Power and Prosperity : Outgrowing Communist and Capitalist Dictatorships, (New York : Basic Books).

Parsons, John E., 1986, "Credit Contracts in the G.D.R.: Decentralized Investment Decisions in a Planned Economy," Economics of Planning, Vol. 20 (No.1), pp. 28-51.

Pollard, Alan P., ed. 1991, USSR: Facts \& Figures Annual, Vol. 15, 1991, (Gulf Breeze Florida: Academic International Press).

Rusek, Antonín, 1989, "Industrial Growth in Czechoslovakia 1971-1985: Total Factor Productivity and Capital-Labor Substitution," Journal of Comparative Economics, Vol. 13 (June), pp.301-13.

Sapir, Andre, 1980, "Economic Growth and Factor Substitution: What Happened to the Yugoslav Miracle?" Economic Journal, Vol. 90 (June), pp. 294-313.

United Nations, Yearbook of National Accounts Statistics, various dates (New York: United Nations, Statistical Office).

Weitzman, Martin L., 1970, "Soviet Postwar Economic Growth and Capital-Labor Substitution.” American Economic Review, Vol. 60, (September), pp. 676-92.

World Bank, 1993, Historically Planned Economies: A Guide to the Data (Washington: World Bank). 